\title{
FAKTOR-FAKTOR PENGARUH KEPUASAAN KERJA AUDITOR PADA BPK RI PROVINSI BALI
}

\author{
A.A Pt. Agung Mirah Purnama Saria, ${ }^{a,}$ I Made Wianto Putra ${ }^{\mathrm{b}}$, I Gst. B. \\ Ngr. P. Putra ${ }^{c}$, Cokorda Krisna Yudha ${ }^{\mathrm{d}}$ \\ a,b.c.d Universitas Warmadewa, Jalan Terompong Nomor 24 Tanjung Bungkak \\ Denpasar, Bali, Indonesia \\ *(agungputumirah@gmail.com)
}

\begin{abstract}
ABSTRAK
Penelitian ini bertujuan untuk mengetahui secara empirisfaktor-faktor pengaruh kepuasan kerja auditor pada BPK RI Provinsi Bali. Faktor-faktor yang digunakan dalam penelitian ini adalah komitmen professional, kompleksitas tugas, locus of control dan time budget pressure. Kepuasan kerja auditor merupakan variabel dependen. Penelitian ini menggunakan sampel sebanyak 50 auditor. Metode penentuan sampel menggunakan kuesioner. Teknik analisis data menggunakan analisis linier berganda. Hasil penelitian membuktikan bahwa komitmen profesional dan locus of control auditor berpengaruh positif pada kepuasan kerja auditor sedangkan kompleksitas tugas dan time budget pressure auditor berpengaruh negatif padakepuasan kerja auditor pada Kantor BPK RI Provinsi Bali.
\end{abstract}

Kata Kunci: Komitmen Professional, Kompleksitas Tugas, Locus of control, Time Budget Pressure dan Kepuasan Kerja.

\section{ABSTRACT}

This study aims to determine empirically factors influencing job satisfaction of auditors at BPK RI Bali Province. Factors used in this research are professional commitment, task complexity, and locus of control and time budget pressure. Auditor job satisfaction is a dependent variable. This study used a sample of 50 auditors. The method of determining sample is using questioner. Data analysis techniques use multiple linear analyses. The result of the research shows that professional commitment and locus of control auditor have positive effect on auditor job satisfaction while task complexity and time budget pressure auditor have negative effect on job satisfaction of auditor at BPK RI office of Bali Province.

Kata Kunci: Professional Commitment, Task Complexity, Locus Of control, Time Budget Pressure and Job Satisfaction. 


\section{PENDAHULUAN}

Pengesahan UU Nomor 6 Tahun 2014 tentang Desa pada 15 Januari 2014 membawa berkah bagi desa- desa di seluruh Indonesia. Undang-undang yang telah melewati proses pembahasan selama 7 tahun tersebut mengatur sumber pendanaan bagi 73ribu desa yang berasal dari sumbangan pemerintah pusat dan suntikan kas daerah. Menurut undangundang tersebut, setiap desa mendapat alokasi danayang jumlahnya cukup banyak bahkan bisa mencapai satu milyar rupiah per desa. UU Desa ini memberi jaminan yang lebih pasti bahwa setiap desa menerima dana dari pemerintah melalui anggaran Negara dan daerah yang jumlahnya berlipat, jauh diatas jumlah yang selama ini tersedia dalam anggaran desa.

Muzirah (2015) berpendapat bahwa hal ini akan menjadikan pemerintah membutuhkan dana yang cukup besar dalam pengelolaan suatu Negara. Oleh karena itu, diperlukan adanya pengawasan yang cukup andal dalam pertanggungjawaban atas penggunaan dana untuk penyelenggaraan pemerintah. Dengan adanya suatu pengawasan yang cukup andal, diharapkan dapat menjamin pendistribusian dana yang merata pada semua sektor public sehingga efektivitas dan efisiensi penggunaan dana bisa dipertanggungjawabkan.

Pemeriksaan Keuangan Negara oleh BPK diamanatkan dalam UndangUndang Dasar 1945 pasal 23 ayat 5 yang berbunyi: "Untuk memeriksa tanggung jawab tentang keuangan Negara diadakan suatu Badan Pemeriksaan Keuangan (BPK) yang pengaturannya ditetapkan dengan Undang-Undang. Hasil pemeriksaan itu diberitahukan kepada Dewan Perwakilan Rakyat (DPR)”. Hasil pemeriksaan tersebut dapat digunakan DPR sebagai salah satu indikator penilaian kinerja pemerintah. Hasil pemeriksaan dari BPK ini menjadi penting, karena secara tidak langsung masyarakat telah memberikan mandat kepada BPK untuk memeriksa apakah penyusunan laporan keuangan oleh Pemerintah sudah dilakukan dengan benar sesuai peraturan yang berlaku.

UU RI No. 17 tahun 2003 tentang keuangan Negara, mengatakan bahwa keuangan Negara adalah semua hak dan kewajiban Negara yang dapat dinilai dengan uang serta segala sesuatu baik berupa uang maupun berupa barang yang dapat dijadikan milik Negara berhubungan dengan pelaksanaan hak dan kewajiban 
tersebut. Berdasarkan UU RI NO. 15 tahun 2006 tentang Badan Pemeriksaan Keuangan, yang dimaksud dengan Badan Pemeriksa Keuangan, yang selanjutnya disingkat BPK, adalah lembaga Negara yang bertugas untuk memeriksa pengelolaan dan tanggung jawab keuangan Negara sebagaimana dimaksud dalam UUD Negara RI Tahun 1945, yang menjelaskan bahwa untuk memeriksa pengelolaan dan tanggungjawab tentang keuangan Negara diadakan satu BPK yang bebas dan mandiri.

BPK merupakan badan pemeriksa eksternal keuangan Negara yang independen dan professional yang mempunyai misi untuk memeriksa pengelolaan dan tanggung jawab keuanganan Negara, dan berperan aktif dalam menemukan dan mencegah segala bentuk penyalahgunaan dan penyelewengan keuangan Negara. Sebagai satu-satunya badan pemeriksa eksternal keuangan Negara, BPK bertugas untuk memeriksa pengelolaan dan tanggungjawab keuangan Negara yang dilakukan oleh pemerintah pusat, pemerintah daerah, lembaga Negara lainnya, Bank Indonesia, Badan Usaha Milik Negara, Badan Layanan Umum, Badan Umum Milik Daerah, dan lembaga atau badan lainnya yang mengelola keuangan Negara. Pemeriksa BPK mencakup pemeriksaan keuangan, pemeriksaan kinerja, dan pemeriksaan dengan tujuan tertentu. Pemeriksaan keuangan yang dilakukan oleh BPK dalam rangka memberikan opini tentang tingkat kewajaran informasi yang disajikan dalam laporan keuangan. Hasil pemeriksaan keuangan Negara diserahkan kepada Dewan Perwakilan Rakyat, dan Dewan Perwakilan Daerah dan Dewan Perwakilan Rakyat Daerah. Dengan adanya BPK diharapkan pengelolaan keuangan Negara dapat dikelola dan pertanggungjawaban secara baik. Karena sesuai dengan UU RI NO. 15 tahun 2004 tentang pemeriksaan pengelolaan dan tanggungjawab keuangan Negara, yang menyebutkan bahwa untuk mendukung keberhasilan penyelenggaraan pemerintahan Negara, keuangan Negara wajib dikelola secara tertib, taat pada peraturan perundangundangan, efisien, ekonomis, efektif, transparan dan bertanggungjawab dengan memperhatikan rasa keadilan dan kepatutan. Agar kinerja audit atas tugas dan fungsi yang dilakukan BPK dapat terlaksana dengan baik maka pada pelaksanaan tugas harus berpedoman pada Standar Pemeriksaan Keuangan Negara (SPKN). 
SPKN adalah penyempurnaan dari Standar Audit Pemerintahan (SAP) 1995. SPKN ini akan mengikat BPK maupun pihak lain yang melaksanakan pemeriksaan keuangan Negara dan atas nama BPK. SPKN berisi tentang persyaratan professional pemeriksa, mutu pelaksana pemeriksa dan organisasi pemeriksa dalam melaksanakan pemeriksaan atas pengelola dan tanggung jawab keuangan Negara. SPKN akan selalu dipantau perkembangannya dan akan selalu dimutakhirkan agar selalu sesuai dinamika yang terjadi dimasyarakat. Saat ini pada lingkungan BPK sudah tidak mengenal auditor, namun sejak diberlakukan UU RI NO. 15 tahun 2006 tentang Badan Pemeriksa Keuangan istilah auditor diganti dengan pemeriksa. Namun dengan alasan untuk memudahkan dalam memberikan penjelasan, pada penelitian ini masih menggunakan istilah auditor sebagai pihak yang bertugas sebagai pemeriksa pada lingkungan BPK.

Suatu permasalahan pada sektor publik tepatnya ada pada lembaga pemerintahan daerah, antara lain adalah tentang ungkapan yang disampaikan oleh Wakil Gubernur DKI Jakarta (Basuki Thahaja Purnama) mengungkapkan keheranannya tentang bagaimana mungkin BPK yang telah mengeluarkan pendapat wajar tanpa pengecualian (WTP) terhadap laporan penggunaan anggaran pemerintah daerah, masih melaporkan adanya potensi kebocoran keuangan daerah sebesar kurang lebih Rp. 400 miliar di sektor fasilitas umum dan fasilitas sosial. Dan ternyata hal serupa tidak hanya dialami oleh Pemerintah daerah DKI Jakarta, banyak daerah lain yang laporan keuangannya memperoleh pendapat WTP, tetapi kemudian dilaporkan adanya penyimpangan anggaran. Dan telah terjadi kasus lain, yakni penangkapan auditor BPK RI Perwakilan Jawa Barat oleh Komisi Pemberantasan Korupsi (KPK) atas kasus penyuapan yang dilakukan oleh oknum Pemerintah Kota Bekasi. Pada sektor wisata swasta juga pernah terjadi suatu kasus skandal besar yang melibatkan Enron, yang merupakan perusahaan energi terbesar di Amerika Serikat dengan Kantor Akuntan Publik (KAP) Arthur Andersen. Beberapa kasus yang terjadi tersebut baik yang telah terjadi di dalam negeri maupun diluar negeri tersebut telah melibatkan auditor, dimana sektor auditor sebagai pihak independen telah melakukan kesalahan mengakibatkan adanya 
suatu bentuk manipulasi hasil audit serta adanya kebocoran dana.

Auditor dituntut untuk dapat menunjukan kinerja yang tinggi agar dapat menghasilkan audit yang berkualitas. Kinerja yang baik dapat dipengaruhi oleh kepuasan kerja yang baik. Jika auditor merasa puas dengan pekerjaannya, kinerja yang dihasilkan juga akan baik. Sebaliknya, apabila auditor merasa tidak puas dengan keadaan pekerjaannya, kinerjanya pun bisa menjadi buruk. Oleh karena itu, kepuasan kerja auditor menjadi penting untuk diteliti.Kepuasan kerja seseorang juga dipengaruhi baik dari dalam maupun luar. Untuk sisi internal, tentu kepuasan kerja seseorang akan menyangkut komitmennya dalam bekerja. Sedangkan dari sisi eksternal, tentu kepuasan kerja akan dipengaruhi oleh lingkungan tempat bekerja, baik dari atasan, bawahan maupun setingkat (Mahardika, 2015).

Kepuasan kerja diartikan sebagai sikap (positif) tenaga kerja terhadap pekerjaannya, yang timbul berdasarkan penilaian terhadap situasi kerja (Umam, 2010). Jika seseorang merasa puas terhadap pekerjaannya maka ia akan lebih bersemangat dalam bekerja sehingga akan memberikan hasil yang baik dan maksimal pada pekerjaannya. Sedangkan jika seseorang memiliki kepuasan kerja yang rendah maka cenderung ia akan kurang bersemangat dalam melaksanakan pekerjaannya sehingga pekerjaan yang di hasilkan kurang maksimal.Kepuasan kerja merupakan suatu perasaan positif tentang pekerjaan seseorang yang merupakan hasil dari sebuah evaluasi karakteristiknya.

Peningkatan kepuasan kerja bagi auditor berkaitan dengan pemenuhan harapan kerja dalam melakukan pemeriksaan. Seorang auditor yang mempunyai tingkat kepuasan kerja tinggi akan menunjukkan kinerjanya dengan baik pula (Gautama dan Muhammad, 2010). Hal-hal yang berhubungan dengan kepuasan kerja yaitu kepuasan dalam hal promosi, kondisi kerja, supervise, praktek organisasi dan hubungan dengan rekan kerja. Kepuasan kerja dapat dipahami melalui tiga aspek yaitu pertama, kepuasan kerja merupakan bentuk respon pekerja terhadap kondisi lingkungan pekerjaan, Kedua, kepuasan kerja sering ditentukan oleh hasil pekerjaan. Ketiga, kepuasan kerja terkait dengan sikap lainnya dan 
dimiliki oleh setiap pekerja (Luthans,2006).

Komitmen merupakan salah satu unsur penting dalam dunia kerja, dan komitmen memiliki hubungan yang positif dengan kinerja. Suatu komitmen profesional merupakan tingkat loyalitas seseorang terhadap pekerjaan yang dilakukannya untuk dapat mencapai tingkat keberhasilan yang tinggi. Keberhasilan yang tinggi akan memberikan hasil yang bernilai tinggi, hal ini akan menimbulkan kepuasan kerja. Penelitiaan yang dilakukan oleh Aryani (2015) menyatakan bahwa Komitmen Profesional berpengaruh positif terhadap kepuasan kerja akuntan pendidik. Sebaliknya penelitian yang dilakukan oleh Aditya (2014) menyatakan bahwa Komitmen Profesional tidak memiliki pengaruh terhadap kepuasan kerja auditor.

Auditor selalu dihadapkan dengan tugas-tugas yang komplek, banyak, berbeda-beda dan saling terkait satu dengan lainnya. Kompleksitas tugas dapat didefinisikan sebagai fungsi dari tugas itu sendiri. Kompleksitas tugas merupakan tugas yang tidak berstruktur, membingungkan dan sulit. Dalam pelaksanaan tugasnya yang kompleks, auditor sebagai anggota pada suatu tim audit memerlukan keahlian, kemampuan, dan tingkat kesabaran yang tinggi (Mohd-Sanusi dan Iskandar, 2007). Adapun penelitian yang dilakukan oleh Hartha (2015) menyatakan bahwa Kompleksitas Tugas berpengaruh positif terhahap kepuasan kerja auditor. Sebaliknya penelitian yang dilakukan oleh Dantha Dewi (2013) menyatakan bahwa Kompleksitas Tugas berpengaruh negatif terhadap kepuasan kerja auditor.

Locus of control merupakan persepsi individu pada suatu kejadian, dapat atau tidaknya individu tersebut dalam mengendalikan suatu kejadian yang terjadi. Chen dan Cholin (2008) mengatakan akuntan yang memiliki locus of control baik dapat mengatasi stress dan lingkungan kerja yang lebih tinggi. Locus of control (LOC) adalah cara pandang seseorang terhadap suatu peristiwa apakah dia dapat atau tidak dapat mengendalikan peristiwa yang terjadi padanya (Rotter, 1966). Menurut Robbins dan Timothy (2008) locus of control dibedakan menjadi internal locus of control dan external locus of control. Karyawan dengan internal control akan tampak melalui kemampuan kerja dan tindakan kerja 
yang berhubungan dengan keberhasilan dan kegagalan karyawan pada saat melakukan pekerjaannya. Sedangkan karyawan dengan external control merasakan bahwa terdapat kontrol diluar dirinya yang mendukung pekerjaan yang dilakukan. Adapun penelitian yang dilakukan Hartha (2015) dan Sari dan Harlina (2015) menyatakan bahwa locus of control berpengaruh positif terhadap kepuasan kerja auditor. Sedangkan penelitian yang dilakukan oleh Aryani (2015) menyatakan bahwa locus of control berpengaruh negatif terhadap kepuasan kerja.

Faktor lain yang mempengaruhi tingkat kepuasan kerja auditor adalah tekanan anggaran waktu atau time budget pressure. Time budget pressure adalah keadaan yang menunjukkan auditor dituntut untuk melakukan efisiensi terhadap anggaran waktu yang telah disusun atau terdapat pembahasan waktu anggaran yang sangat ketat dan kaku (Sososutikno, 2003). Hal ini tidak bisa lepas dari pekerjaan auditor, karena auditor seringkali bekerja dalam keterbatasan waktu. Tuntutan laporan yang berkualitas dengan anggaran waktu tebatas tentu saja merupakan tekanan tersendiri bagi auditor. Oleh karena itu, tekanan waktu juga dapat mempengaruhi kepuasan kerja seorang auditor. Penelitian Sari dan Harlina (2015) yang menyatakan bahwa time budget pressure berpengaruh positif terhadap kepuasan kerja auditor. Sebaliknya penelitian Dantha Dewi (2013) menyatakan bahwa time budget pressure berpengaruh negatif terhadap kepuasan kerja auditor.

Penelitian ini bertujuan untuk membuktikan secara empiris faktorfaktor pengaruh kepuasan kerja auditor pada BPK Provinsi Bali. Beberapa faktor yang digunakan dalam penelitian ini adalah komitmen professional, kompleksitas tugas, locus of control, dan time budget pressure. Ruang lingkup pada penelitian ini adalah terbatas pada komitmen profesional, kompleksitas tugas, locus of control, time budget pressure dan kepuasan auditor pada BPK Perwakilan Provinsi Bali.

\section{TINJAUAN PUSTAKA DAN PERUMUSAN HIPOTESIS}

Teori yang digunakan dalam penelitian ini adalah teori dua faktor (Two Factor Theory) dan Value Theory. Two Factor Theory merupakan teori kepuasan kerja yang menganjurkan bahwa satisfaction (kepuasan) dan 
dissatisfaction (ketidakpuasan) merupakan bagian dari kelompok variabel yang berbeda, yaitu motivators dan hygiene factor.Pada teori ini ketidakpuasan dihubungkan dengan kondisi disekitar pekerjaan (seperti kondisi kerja, upah, keamanan, dan kualitas pengawasan) dan bukan dengan pekerjaan itu sendiri.Faktor mencegah reaksi negatif dinamakan sebagai hygiene atau maintenance factors. Sebaliknya kepuasan ditarik dari beberapa faktor yang terkait dengan pekerjaan itu sendiri ataau hasil langsung dari padanya seperti sifat pekerjaan, prestasi dalam pekerjaan, peluang promosi dan kesempatan untuk pengembangan diri dan pengakuan, karena faktor ini berkaitan dengan tingkat kepuasan kerja tinggi dinamakan motivators. Sedangkan Value Theory menyatakan bahwa kepuasan kerja dapat diperoleh dari banyak faktor, oleh karena itu cara yang efektif untuk memuaskan pekerja adalah dengan menemukan apa yang mereka inginkan dan apabila mungkin memberikannya (Wibowo, 2015).

Auditing adalah suatu proses sistematik untuk memperoleh dan mengevaluasi bukti secara objektif mengenai pernyataan-pernyataan tentang kegiatan dan kejadian ekonomi, dengan tujuan untuk menetapkan tingkat kesesuaian antara pernyataan-pernyataan tersebut dengan kriteria yang telah ditetapkan, serta penyampaian hasil kepada pemakai yang berkepentingan (Mulyadi, 2014). Auditor digolongkan menjadi tiga golongan menurut Mulyadi (2014), yaitu:

a. Auditor Independen

Auditor independen adalah auditor profesional yang menyediakan jasanya kepada masyarakat umum, terutama dalam bidang audit atas laporan keuangan yang dibuat oleh kliennya. Auditor tersebut terutama ditujukan untuk memenuhi kebutuhan para pemakai informasi keuangan seperti: kreditur, investor, calon kreditur, calon investor, dan instansi pemerintah.

b. Auditor Pemerintah

Auditor pemerintah adalah auditor profesional yang bekerja di instansi pemerintah yang tugas pokoknya melakukan audit atas pertanggungjawaban keuangan yang disajikan oleh unit-unit organisasi atau entitas pemerintahan atau pertanggungjawaban keuangan yang ditujukan kepada pemerintah. 
Umumnya yang disebut auditor pemerintah adalah auditor yang bekerja di Badan Pengawasan Keuangan dan Pembangunan (BPKP) dan Badan Pemeriksa Keuangan (BPK), serta instansi pajak.

c. Auditor Intern

Auditor intern adalah auditor yang bekerja dalam perusahaan (perusahaan negara maupun perusahaan swasta) yang tugas pokoknya adalah menentukan apakah kebijakan dan prosedur yang ditetapkan oleh manajemen puncak telah dipatuhi, menentukan baik atau tidaknya penjagaan terhadap kekayaan organisasi, menentukan efisiensi dan evektifitas prosedur kegiatan organisasi, serta menentukan keandalan informasi yang dihasilkan oleh berbagai bagian organisasi.

Selain auditor, BPK juga memiliki wewenang memeriksa pengelolaan dan tanggung jawab keuangan negara. BPK adalah lembaga tinggi negara da;am system ketatanegaraan Indonesia. BPK masuk dalam kategori lembaga yang mandiri dan bebas, pernyataan ini sebagaimana tercantum dalam UUD 1945.Anggota BPK dipilih oleh DPR dengan tetap mempertimbangkan DPD dan kemudian diresmikan oleh Presiden.Keberadaan BPK telah diatur dengan tugas dan fungsi BPK pada pasal 23 ayat (5) UUD Tahun 1945 yang menetapkan bahwa, memeriksa tanggung jawab tentang Keuangan Negara. Yang diadakan pada suatu Badan Pemeriksa Keuangan yang peraturannya ditetapkan oleh UndangUndang, kemudian hasil pemeriksaan yang dilakukan itu akan disampaikan kepada Dewan Perwakilan Rakyat.

Tingkat keinginan untuk mempertahankan sikap professional antara satu auditor dengan auditor lainnya, tergantung persepsi individu masing-masing. Hal ini tentunya akan menentukan nuansa komitmen profesional yang berbeda-beda (Mulyadi, 2014).Apabila komitmen profesional auditor ditingkatkan, maka akan menyebabkan naiknya kepuasan kerja auditor. Penelitian yang dilakukan oleh Aryani (2015) menyatakan bahwa komitmen profesional berpengaruh positif dan signifikan terhadap kepuasan kerja auditor. Ini disebabkan karna dengan adanya komitmen profesional yang tinggi, maka seorang auditor akan menghasilkan pekerjaan yang berkualitas sekaligus sebagai jaminan 
keberhasilan atas tugas-tugas tersebut, sehingga dari keberhasilan yang dicapai kepuasan kerja auditor juga akan meningkat. Dari hasil penelitian sebelumnya tersebut maka penulis mengajukan hipotesis pertama sebagai berikut:

$\mathrm{H}_{1}$ : Komitmen profesional berpengaruh positif terhadap kepuasan kerja auditor pada BPK RI Provinsi Bali.

Kompleksitas tugas didefinisikan sebagai tugas yang kompleks, terdiri atas bagian-bagian yang banyak, berbeda-beda dan saling terkait satu sama lain. Tingginya kompleksitas penugasan ini menuntut auditor untuk terus meningkatkan kemampuan daya pikir dan kesabaran dalam penyelesaian tugas, karena kompleksitas tugas merupakan tugas yang tidak terstruktur, membingungkan, dan sulit. (MohdSanusi dan Iskandar, 2007)

Penelitian yang dilakukan oleh Hartha (2015) menunjukkan bahwa kompleksitas tugas berpengaruh positif dan signifikan terhadap kepuasan kerja auditor. Dari hasil penelitian sebelumnya tersebut maka penulis mengajukan hipotesis kedua sebagai berikut:
$\mathrm{H}_{2}$ : Kompleksitas tugas berpengaruh positif pada kepuasan kerja auditor pada BPK RI Provinsi Bali.

Locus of control merupakan cara pandang seseorang terhadap suatu peristiwa apakah dia dapat atau tidak mengendalikan peristiwa yang terjadi padanya (Robbins dan Timothy, 2008). Dengan menggunakan locus of control perilaku kerja dapat dilihat melalui penilaian karyawan terhadap hasil mereka saat dikontrol secara internal maupun secara eksternal yang dapat mempengaruhi hasil melalui kemampuan. Penelitian yang dilakukan oleh Hartha (2015) bahwa locus of control berpengaruh positif dan signifikan pada kepuasan kerja. Dari hasil penelitian sebelumnya tersebut maka penulis mengajukan hipotesis ketiga sebagai berikut:

$\mathrm{H}_{3}$ : Locus of control berpengaruh positif padakepuasan kerjaauditor pada BPK RI Provinsi Bali.

Time budget pressure didefinisikan sebagai suatu bagian dari perencanaan yang digunakan auditor untuk menetapkan panduan dalam satuan waktu jam untuk setiap langkah audit (Ahmadie, 2009). Time budget pressure yang dimaksud dalam penelitian ini adalah keadaan dimana 
auditor dituntut untuk melakukan efisiensi terhadap anggaran waktu yang telah disusun atau bisa dikatakan terdapat pembahasan waktu anggaran yang sangat ketat dan kaku. Penelitian yang dilakukan oleh Dutadasanovan (2015) menyatakan bahwa time budget pressure berpengaruh positif dan signifikan terhadap kepuasan auditor.Di mana semakin tinggitime budget pressure maka semakin menurun kepuasan kerja yang dirasakan auditor. Dari hasil penelitian sebelumnya tersebut maka penulis mengajukan hipotesis keempat sebagai berikut:

$\mathrm{H}_{4}$ : Time Budget Pressure berpengaruh positif terhadap kepuasan kerjaauditor pada BPK RI Provinsi Bali.

\section{METODE PENELITIAN}

Populasi yang digunakan dalam penelitian ini seluruh auditor yang bekerja pada lingkungan BPK RI perwakilan Provinsi Bali yang berjumlah 50 orang fungsional auditor. Penelitian ini menggunakan jenis data kuantitatif dan kuesioner diukur dengan skala Likert. Penelitian ini juga menggunakan data kualitatif yang berupa berupa keterangan yang dapat memberikan informasi mengenai latar belakang atau sejarah BPK RI Provinsi Bali. Data yang digunakan dalam penelitian ini merupakan data primer yang diperoleh langsung dari responden yang bersumber dari kuesioner. Data diperoleh langsung dari jawaban kuesioner yang dikirim pada BPK RI. Metode pengumpulan data yang digunakan adalah metode survey dengan menggunakan kuesioner yang diadopsi dari penelitian sebelumnya. Kuesioner dalam penelitian ini bersifat tertutup dimana alternatif-alternatif jawaban telah disediakan. Kuesioner yang disebar berkaitan dengan komitmen profesional, kompleksitas tugas, locus of control, dan time budget pressure pada kepuasan kerja auditor yang diantarkan langsung ke Kantor BPK RI Provinsi Bali yang bersangkutan. Jawaban dari responden atas kuisioner diukur dengan menggunakan empat alternatif jawaban yang disediakan, yaitu Sangat Setuju (SS), Setuju (S), Cukup Setuju (CS) Tidak Setuju (TS), dan Sangat Tidak Setuju (STS). Penelitian ini menggunakan dua variabel, yaitu (1) variabel terikat $(\mathrm{Y})$, yaitu kepuasan kerja auditor, (2) variabel bebas $(\mathrm{X})$, yaitu komitmen professional, kompleksitas tugas, locus of control, dan time budget pressure. 
Variabel-variabel ini diuji dengan menggunakan skala likert 1 sampai 5 yaitu, jawaban SS (Sangat Setuju) memiliki skor 5, jawaban S (Setuju) memiliki skor 4, jawaban CS (Cukup Setuju) memiliki skor 3, jawaban TS (Tidak Setuju) memiliki skor 2, dan jawaban STS (Sangat Tidak Setuju) memiliki skor 1. Teknik analisis data yang digunakan dalam penelitian ini adalah (1) uji kualitas data yang terdiri dari uji validitas dan uji reliabilitas, (2) uji asumsi klasik yang terdiri dari uji normalitas, uji multikolonieritas, dan

\section{HASIL DAN PEMBAHASAN}

Penelitian ini dilakukan pada Badan Pemeriksa Keuangan (BPK) Provinsi Bali. Data dalam penelitian ini diperoleh dari hasil kuisioner yang telah dilakukan peneliti dengan responden untuk mendapatkan data yang lebih akurat dan memudahkan dalam proses analisis data. Penyebaran kuisioner menggunakan sampel penelitian sebanyak 50 orang uji heteroskedastisitas, (3) analisis data menggunakan metode analisis linier berganda dengan model persamaan adalah sebagai berikut:

$Y=a+\beta_{1} X_{1}+\beta_{2} X_{2}+\beta 3 X 3+e$

Keterangan:

Y : Kepuasan kerja auditor

a : Nilai konstanta

$\beta_{1,} \beta_{2}, \beta_{3}, \beta_{4}, \beta_{5}$ : Koefisien regresi

$\mathrm{X}_{1} \quad$ : Komitmen professional

$\mathrm{X}_{2} \quad$ : Kompleksitas tugas

$\mathrm{X}_{3} \quad$ : Locus of control

$\mathrm{X}_{4} \quad$ : Time budget pressure

e : Error

fungsional auditor yang bekerja pada BPK RI perwakilan Provinsi Bali. Jumlah kuisioner kembali sebanyak 38 kuisioner sedangkan jumlah kuisioner yang tidak kembali sebanyak 12 kuisioner. Proses pendistribusian hingga pengumpulan data dilakukan kurang lebih dua minggu terhitung sejak tanggal 25 Januari s/d 8 Februari 2018. Jumlah kuisioner yang disebar dan jumlah kuisioner yang tidak kembali disajikan pada Tabel 1:

Tabel 1. Jumlah Kuisioner Kembali

\begin{tabular}{cc}
\hline Keterangan & Jumlah \\
\hline Kuisioner yang disebar & 50 \\
Kuisioner yang tidak kembali & $(12)$ \\
Total kuisioner kembali & 38 \\
\hline
\end{tabular}

Sumber: Data diolah (2018) 
Data penelitian ini diperoleh dari hasil kuesioner yang telah disebarkan kepada responden penelitian berjumlah 38 (tiga puluh delapan)orang fungsional auditor yang bekerja pada Badan Pemeriksa Keuangan (BPK) RI Perwakilan Provinsi Bali. Karakteristik responden yang diteliti meliputi: umur, jenis kelamin, pendidikan terakhir dan lama bekerja sebagai auditor. Ringkasan mengenai karakteristik responden disajikan pada Tabel 2 sebagai berikut:

Tabel 2. Demografi Responden

\begin{tabular}{lcc}
\hline \multicolumn{1}{c}{ Keterangan } & Frekuensi & Persentase (\%) \\
\hline 1. Umur & 35 & $92,1 \%$ \\
a) 20-29 tahun & 0 & $0,0 \%$ \\
b) 30-39 tahun & 2 & $5,3 \%$ \\
c) 40-49 tahun & 1 & $2,6 \%$ \\
d) Lebih dari 50 tahun & 38 & $100 \%$ \\
Jumlah & & \\
2. Jenis Kelamin & 20 & $52,6 \%$ \\
a) Laki-laki & 18 & $47,4 \%$ \\
b) Perempuan & 38 & $100 \%$ \\
Jumlah & & \\
3. Pendidikan Terakhir & 0 & $0,0 \%$ \\
a) SMA/SMK & 3 & $7,9 \%$ \\
b) D3 & 31 & $81,6 \%$ \\
c) S1 & 4 & $10,5 \%$ \\
d) S2 & & \\
Jumlah & 38 & $100 \%$ \\
& & \\
4. Pengalaman bertugas di BPK & 34 & $89,5 \%$ \\
a) 1-5 tahun & 4 & $10,5 \%$ \\
b) > tahun s/d 10 tahun & 38 & $100 \%$ \\
Jumlah
\end{tabular}

Sumber: Data diolah (2018)

Setelah dilakukan pembahasan mengenai gambaran umum responden serta karakteristik responden yang meliputi jenis kelamin, umur, pendidikan, dan masa bekerja, maka langkah selanjutnya adalah menganalisis jawaban-jawaban responden terhadap keterkaitan beberapa faktor dalam penelitian ini yaitu dengan uji kualitas data meliputi uji validitas dan uji realibilitas. Tabel di bawah menunjukkan skor pada masing-masing variabel adalah valid, karena tiap skor lebih dari 0,3. Hasil uji validitas instrumen ditunjukkan pada Tabel 3 berikut. 
Tabel 3. Hasil Uji Validitas

\begin{tabular}{|c|c|c|c|c|}
\hline No & Variabel & Pertanyaan & $\begin{array}{c}\text { Pearson } \\
\text { Correlation }\end{array}$ & Keterangan \\
\hline \multirow{8}{*}{1} & \multirow{8}{*}{$\begin{array}{c}\text { Komitmen } \\
\text { Profesional (X1) }\end{array}$} & $\mathrm{X} 1.1$ & 0,553 & Valid \\
\hline & & $\mathrm{X} 1.2$ & 0,613 & Valid \\
\hline & & $\mathrm{X} 1.3$ & 0,724 & Valid \\
\hline & & $\mathrm{X} 1.4$ & 0,563 & Valid \\
\hline & & $X 1.5$ & 0,552 & Valid \\
\hline & & $X 1.6$ & 0,726 & Valid \\
\hline & & $\mathrm{X} 1.7$ & 0,523 & Valid \\
\hline & & $\mathrm{X} 1.8$ & 0,614 & Valid \\
\hline \multirow{6}{*}{2} & \multirow{6}{*}{$\begin{array}{c}\text { Kompleksitas } \\
\text { Tugas } \\
\text { (X2) }\end{array}$} & $\mathrm{X} 2.1$ & 0,795 & Valid \\
\hline & & $\mathrm{X} 2.2$ & 0,873 & Valid \\
\hline & & $X 2.3$ & 0,792 & Valid \\
\hline & & $X 2.4$ & 0,829 & Valid \\
\hline & & $X 2.5$ & 0,767 & Valid \\
\hline & & X2.6 & 0,648 & Valid \\
\hline \multirow{8}{*}{3} & \multirow{8}{*}{$\begin{array}{c}\text { Locus of Control } \\
\text { (X3) }\end{array}$} & X3.1 & 0,642 & Valid \\
\hline & & X3.2 & 0,547 & Valid \\
\hline & & X3.3 & 0,711 & Valid \\
\hline & & X3.4 & 0,707 & Valid \\
\hline & & X3.5 & 0,550 & Valid \\
\hline & & X3.6 & 0,522 & Valid \\
\hline & & X3.7 & 0,560 & Valid \\
\hline & & X3.8 & 0,553 & Valid \\
\hline \multirow{7}{*}{4} & \multirow{7}{*}{$\begin{array}{c}\text { Time Budget } \\
\text { Pressure } \\
\text { (X4) }\end{array}$} & X4.1 & 0,575 & Valid \\
\hline & & $\mathrm{X} 4.2$ & 0,600 & Valid \\
\hline & & $X 4.3$ & 0,750 & Valid \\
\hline & & $X 4.4$ & 0,710 & Valid \\
\hline & & $X 4.5$ & 0,643 & Valid \\
\hline & & $X 4.6$ & 0,604 & Valid \\
\hline & & $X 4.7$ & 0,622 & Valid \\
\hline \multirow{8}{*}{5} & \multirow{8}{*}{$\begin{array}{c}\text { Kepuasan Kerja } \\
\text { Auditor } \\
(\mathrm{Y})\end{array}$} & Y.1 & 0,726 & Valid \\
\hline & & Y.2 & 0,761 & Valid \\
\hline & & Y.3 & 0,795 & Valid \\
\hline & & Y.4 & 0,788 & Valid \\
\hline & & Y.5 & 0,637 & Valid \\
\hline & & Y.6 & 0,750 & Valid \\
\hline & & Y.7 & 0,763 & Valid \\
\hline & & Y.8 & 0,862 & Valid \\
\hline
\end{tabular}

Sumber: Data diolah $(2018)$

Berdasarkan Tabel 3 hasil uji validitas di atas, disimpulkan bahwa seluruh item pertanyaan yang digunakan dalam penelitian ini adalah valid, hal ini bisa dilihat dari masingmasing item pertanyaan memiliki nilai Pearson Correlation yang lebih besar dari 0,30 sehingga telah memenuhi 
syarat validitas data.

Suatu kuisioner dikatakan reliabel atau handal jika jawaban seseorang terhadap pertanyaan adalah konsisten atau stabil dari waktu ke waktu. Suatu instrumen dikatakan reliabel apabila nilai cronbach alpha lebih besar dari 0,7 (Ghozali, 2013).

Tabel 4.

Hasil Uji Reliabilitas

\begin{tabular}{clcl}
\hline No & \multicolumn{1}{c}{ Variabel } & $\begin{array}{c}\text { Cronbach } \\
\text { Alpha }\end{array}$ & Keterangan \\
\hline 1 & Komitmen Profesional (X1) & 0,765 & Reliabel \\
2 & Kompleksitas Tugas (X2) & 0,869 & Reliabel \\
3 & Locus of Control (X3) & 0,736 & Reliabel \\
4 & Time Budget Pressure (X4) & 0,773 & Reliabel \\
5 & Kepuasan Kerja Auditor (Y) & 0,892 & Reliabel \\
\hline
\end{tabular}

Sumber: Data diolah (2018)

Berdasarkan penjelasan yang telah dikemukakan bahwa, apabila nilai cronbach alpha lebih besar dari 0,7 maka instrumen tersebut dikatakan reliabel. Tabel diatas menunjukkan bahwa masing-masing variabel adalah reliabel, karena masing-masing variabel memiliki skor lebih dari 0,7.

Uji Asumsi Klasik

$$
\text { Hasil uji normalitas pada }
$$
penelitian ini adalah sebesar 0,572 sedangkan nilai Asymp. Sig (2-tailed) sebesar 0,899. Hasil tersebut mengindikasikan bahwa model persamaan regresi berdistribusi normal karena nilai Asymp. Sig (2-tailed) 0,899 lebih besar dari alpha 0,05. Hasil uji multikolinearitas menunjukkan bahwa nilai tolerance dari variabel bebas (independen) $>0,10$ dan nilai VIF $\leq 10$, maka dapat disimpulkan bahwa tidak terjadi gejala multikolinearitas antara variabel bebas dalam model regresi. Hasil uji heteroskedastisitas menunjukkan bahwa semua variabel bebas memiliki nilai signifikansi yaitu: 0,$801 ; \quad 0,665 ; \quad 0,253 ; \quad$ dan 0,333 menunjukkan bahwa nilai signifikansinya $>0,05$ maka dapat disimpulkan bahwa tidak terdapat gejala heteroskedastisitas.

Hasil koefisien determinasi (AdjustedR2) adalah 0,493 atau sebesar 
49,3 persen. Hal ini berarti kepuasan kerja audit mampu dijelaskan sebesar 49,3 persen oleh variabel komitmen profesional, kompleksitas tugas, locus of control dan time budget pressure. Sedangkan sisanya 50,7 persen dipengaruhi oleh faktor-faktor lain yang tidak dimasukkan kedalam model penelitian. Hasil uji $\mathrm{F}$ menunjukkan nilai signifikansi sebesar 0,000 yang lebih kecil dari 0,05. Maka model regresi dikatakan fit atau layak untuk menguji data selanjutnya.
Analisis Pengaruh Komitmen Profesional padaKepuasan Kerja Auditor

Berdasarkan tabel 5 dibawah ini, diketahui bahwa komitmen profesional berpengaruh positif terhadap kepuasan kerja auditordengan koefisien regresi sebesar 0,482dengan nilai signifikansi sebesar $0,003<0,05$ sehingga $\mathrm{H}_{1}$ diterima.

Tabel 5 Hasil Uji t

Coefficients $^{a}$

\begin{tabular}{|c|c|c|c|c|c|c|}
\hline \multirow{3}{*}{\multicolumn{2}{|c|}{ Model }} & \multirow{2}{*}{\multicolumn{2}{|c|}{$\begin{array}{l}\text { Unstandardized } \\
\text { Coefficients }\end{array}$}} & \multirow{3}{*}{$\begin{array}{c}\text { Standardized } \\
\text { Coefficients } \\
\text { Beta }\end{array}$} & \multirow[t]{3}{*}{$\mathrm{t}$} & \multirow[t]{3}{*}{ Sig. } \\
\hline & & & & & & \\
\hline & & B & Std. Error & & & \\
\hline \multirow{5}{*}{1} & (Constant) & 3,057 & 4,695 & & ,651 &, 520 \\
\hline & Komitmen Profesional & ,523 & , 164 & ,482 & 3,189 & ,003 \\
\hline & Kompleksitas Tugas &,- 109 & ,233 &,- 073 &,- 466 & ,644 \\
\hline & Locus of Control &, 569 & , 179 & , 498 & 3,184 & ,003 \\
\hline & Time Budget Pressure &,- 119 & 146 &,- 113 &,- 811 & ,423 \\
\hline
\end{tabular}

a. Dependent Variable: Kepuasan Kerja Auditor

Sumber: Data diolah (2018)

Hal tersebut mengindikasikan bahwa semakin tinggi komitmen professional seorang fungsional auditor maka semakin baik pula kepuasan kerja audit. Komitmen profesional merupakan tingkat loyalitas individu pada profesinya seperti yang dipersepsikan oleh individu tersebut. Komitmen profesional mendasari perilaku, sikap, dan orientasi seseorang dalam menjalankan tugasnya atau pekerjaannya. Komitmen profesional 
yang didasari oleh pemahaman perilaku, sikap dan orientasi profesional dalam melaksanakan tugas merupakan cerminan dari normanorma, aturan dan kode etik profesinya. Dalam melaksanakan tugas sebagai profesional, setiap auditor harus senantiasa menggunakan pertimbangan moral dan profesional dalam semua kegiatan yang dilakukannya. Dengan adanya komitmen profesional yang tinggi, maka seorang auditor akan menghasilkan pekerjaan yang berkualitas sekaligus sebagai jaminan keberhasilan atas tugas-tugas tersebut, sehingga dari keberhasilan yang dicapai kepuasan kerja auditor juga akan meningkat.

Hasil penelitian ini sejalan dengan penelitian terdahulu yang dilakukan olehSari dan Harlina (2015) dan Aryani (2015) yang menunjukkan bahwa komitmen profesional berpengaruh positif pada kepuasan kerja auditor.

Analisis Pengaruh Kompleksitas Tugas pada Kepuasan Kerja Auditor

Berdasarkan Tabel 5 diatas, diketahui bahwa kompleksitas tugas tidak berpengaruh padakepuasan kerja auditor dengan koefisien regresi sebesar -0,073dengan nilai signifikansi sebesar $0,644>0,05$ sehingga $\mathrm{H}_{2}$ ditolak. Kompleksitas tugas merupakan tugas yang tidak terstruktur, membingungkan, dan sulit. Kompleksitas tugas pada penelitian ini didefinisikan sebagai tugas yang kompleks, terdiri atas bagian-bagian yang banyak, berbeda-beda, dan saling terkait satu sama lain. Dalam pelaksanaan tugasnya yang kompleks, auditor sebagai anggota pada suatu tim audit memerlukan keahlian, kemampuan, dan tingkat kesabaran yang tinggi. Tingginya kompleksitas penugasan ini menuntut auditor untuk terus meningkatkan kemampuan daya pikir dan kesabaran dalam penyelesaian tugas, karena kompleksitas tugas merupakan tugas yang tidak terstruktur, membingungkan, dan sulit. Hal tersebut dapat menyebabkan auditor kewalahan, stres, tertekan dan dapat pula timbul rasa bosan karena harus dihadapkan dengan situasi / kondisi sedemikian rupa selama berhari-hari. Dengan demikian, hasil audit yang dihasilkan oleh auditor tidak dapat maksimal dan kurang mampu memberikan pelayanan yang baik, sehingga akan timbul rasa yang tidak puas terhadap kinerja seorang auditor.

Hasil penelitian ini sejalan dengan penelitian terdahulu yang 
dilakukan oleh Dantha Dewi (2013)menunjukkan bahwa kompleksitas tugasberpengaruh negatif terhadap kepuasan kerja auditor. Sedangkan penelitian yang dilakukan oleh Hartha (2015)menunjukkan bahwa kompleksitas tugas berpengaruh positif terhadap kepuasan kerja auditor.

Analisis Pengaruh Locus of Control pada Kepuasan Kerja Auditor

Berdasarkan Tabel 5 diatas, diketahui bahwa locus of controlberpengaruh positif terhadap kepuasan kerja auditor dengan koefisien regresi sebesar 0,498dengan nilai signifikansi sebesar $0,003<0,05$ sehingga $\mathrm{H}_{3}$ diterima. Locus of control (LOC) atau sumber kendali dalam pandangan beberapa orang meyakini bahwa mereka yang menentukan nasib mereka sendiri. Locus of controlmerupakan cara pandang seseorang terhadap suatu peristiwa apakah dia dapat atau tidak mengendalikan peristiwa yang terjadi padanya. Dengan menggunakan locus of control perilaku kerja dapat dilihat melalui penilaian karyawan terhadap hasil mereka saat dikontrol secara internal maupun secara eksternal yang dapat mempengaruhi hasil melalui kemampuan. Hal tersebut mengindikasikan bahwa dengan lotus of control seorang auditor dapat menilai hasil kerja mereka dan dapat menentukan tingkat kepuasan kerja yang ingin mereka capai, sehingga semakin tinggi locus of control maka tingkat kepuasan kerja auditor akan semakin tinggi pula.

Hasil penelitian ini sejalan dengan penelitian terdahulu yang dilakukan oleh Hartha (2015) menunjukkan bahwa locus of controlberpengaruh positif terhadap kepuasan kerja auditor.

Analisis Pengaruh Time Budget Pressure pada Kepuasan Kerja Auditor

Berdasarkan pada Tabel 5 diatas, diketahui bahwa time budget pressure tidak berpengaruh terhadap kepuasan kerja auditor dengan koefisien regresi sebesar -0,113dengan nilai signifikansi sebesar $0,423>0,05$ sehingga $\mathrm{H}_{4}$ ditolak.Time budget pressure didefinisikan sebagai suatu bagian dari perencanaan yang digunakan auditor untuk menetapkan panduan dalam satuan waktu jam untuk setiap langkah audit. Ada sedikit pertanyaan bahwa anggaran waktu penting untuk perencanaan dan pengendalian tugas audit. Namun literatur empiris menunjukkan bahwa, untuk kedua faktor auditor internal dan ekternal, anggaran waktu 
merupakan pengetatan dan semakin menganggu upaya untuk memastikan kualitas audit sehingga akan berdampak terhadap kepuasan kerja auditor. Literatur juga menjelaskan bahwa meningkatnya persaingan di pasar audit penyebab utama karena meningkatkan tekanan untuk memaksimalkan efesiensi dan pengendalian biaya. Adanya batas waktu penyelesaian audit membuat auditor mempunyai masa sibuk yang menuntut agar dapat bekerja dengan cepat. Anggaran yang ketat sering kali mendorong auditor untuk membuang bagian-bagian dari program audit dan dengan demikian dapat menurunkan kualitas audit. Seorang auditor yang bekerja dalam tekanan anggaran waktu sangat mempengaruhi kinerjanya sehingga tidak akan meningkatkan kepuasan kerja auditor.

Hasil penelitian ini sejalan dengan penelitian terdahulu yang dilakukan oleh Dantha Dewi (2013) menunjukkan bahwa time budget pressure berpengaruh negatif terhadap kepuasan kerja auditor. Sedangkan penelitian dilakukan olehDutadasanovan (2013) menunjukkan bahwa time budget pressure berpengaruh positif terhadap kepuasan kerja auditor.

\section{KESIMPULAN, IMPLIKASI DAN KETERBATASAN}

Penelitian ini bertujuan untuk mengetahui apakah faktor-faktor pengaruh kepuasan kerja auditor pada BPK RI Provinsi Bali. Faktor-faktor yang diteliti adalah komitmen profesional, kompleksitas tugas, locus of control dan time budget pressure. Dalam penelitian ini populasi dan sampel yang digunakan adalah 50 orang auditor yang bekerja pada kantor Badan Periksa Keuangan di Provinsi Bali. Untuk menganalisis data menggunakan teknik analisis regresi linear berganda. Berdasarkan hasil analisis data, dapat disimpulkan hasil penelitian sebagai berikut:

1. Komitmen Profesional berpengaruh positif terhadap kepuasan kerja auditor pada Badan Pemeriksa Keuangan (BPK) RI Provinsi Bali.

2. Kompleksitas Tugas berpengaruh negatif terhadap terhadap kepuasan kerja auditor pada Badan Pemeriksa Keuangan (BPK) RI Provinsi Bali.

3. Locus of Control berpengaruh positif terhadap terhadap kepuasan kerja auditor pada Badan Pemeriksa Keuangan (BPK) RI Provinsi Bali. 
4. Time Budget Pressure berpengaruh negatif terhadap kepuasan kerja auditor pada Badan Pemeriksa Keuangan (BPK) RI Provinsi Bali.

Beberapa keterbatasan dan juga saran yang ada dalam penelitian ini yaitu:

1) Komitmen profesional dari dalam diri auditor perlu lebih ditekankan karena adanya tekad dan harapan akan menuntun auditor bertindak dan bekerja sesuai prosedurprosedur dalam upaya menjalankan tugasnya dengan tingkat keberhasilan yang tinggi sehingga mampu memberikan kinerja yang baik dengan pemberian reward sehingga kepuasan kerja dapat tercapai.

2) Kompleksitas tugas merupakan tugas yang tidak berstruktur, membingungkan dan sulit. Agar kepuasan kerja tercapai maka kompleksitas harus tetap dibatasi oleh struktur tugas yang berlaku.

3) Locus of controlmerupakan cara pandang seseorang terhadap suatu peristiwa apakah dia dapat atau tidak mengendalikan peristiwa yang terjadi padanya. Locus of control seorang auditor dapat menilai hasil kerja mereka dan dapat menentukan tingkat kepuasan kerja yang ingin mereka capai, sehingga semakin tinggi locus of control maka tingkat kepuasan kerja auditor akan semakin tinggi pula.

4) Tekanan anggaran waktu (time budget pressure) merupakan bentuk tekanan yang muncul dari keterbatasan sumber daya yang diberikan untuk melaksanakan tugas. Sumber daya yang dimaksud adalah waktu yang diperlukan dan digunakan oleh auditor dalam melaksanakan audit. Agar kepuasan kerja tercapai maka Auditor harus pandai dalam mengestimasikan waktunya dalam melakukan audit, sehingga dapat mengaudit tanpa merasa terbebankan. Membagi waktu dan bekerja dengan cepat dalam mengaudit, serta mengumpulkan bukti yang mendukung dalam laporan auditnya.

5) Kesibukan dari responden dalam mengerjakan pekerjaannya ketika peneliti melakukan pengisian kuisioner menjadi tidak efisien, hal tersebut yang menyebabkan peneliti beberapa kali menemui responden. Saran untuk peneliti selanjutnya agar memastikan waktu pengisian kuisioner sebaiknya dalam keadaan santai 
sehingga kegiatan dapat berjalan dengan lancar.

6) Dalam penelitian ini hanya menguji variabel komitmen profesional, kompleksitas tugas, locus of control dan time budget pressure. Bagi peneliti selanjutnya dapat menambahkan faktor lain yang mempengaruhi kepuasan kerja auditor seperti; kompensasi finansial, komitmen organisasi, konflik peran dan independensi.

\section{DAFTAR PUSTAKA}

Aditya, A.A \& Made Gede Wirakusuma. 2014. Pengaruh Komitmen Profesional pada Kepuasan Kerja Auditor dengan Motivasi sebagai Variabel Moderasi. Universitas Udayana. Skripsi

Ahmadie, Hazmi. 2009. Pengaruh Time Budget Pressure terhadap Perilaku Penurunan Kualitas Audit. Universitas Pendidikan Indonesia. Skripsi

Aryani, Komang Trisna, (2015), Pengaruh Komitmen Profesional, Kelebihan Beban Kerja, dan Komitmen Profesional, Serta Locus of Control Pada Kepuasan Kerja Akuntan Pendidik, Skripsi S-1 Fakultas Ekonomi dan Bisnis Universitas Udayana (Unud), Bali.

Chen, Jui-Chen and Colin Silverthorne. 2008. The Impact of Locus of Control on Job Stress, Job Performance and Job
Statisfaction in Taiwan. Leadership \& Organization Development Journal. Vol 29, No. 7, Juni: 572-582

Dantha Dewi, Divie, (2013), Pengaruh Gaya Kepemimpinan, Kompleksitas Tugas, Time Budget Pressure, dan Komitmen Organisasi Terhadap Kepuasan Kerja Auditor Pada KAP di Yogyakarta, Skripsi S-1 Fakultas Ekonomi Universitas Negeri Yogyakarta.

Dutadasanovan, Yoga. 2013. Pengaruh Time Budget Pressure terhadap Kualitas Audit dengan Independensi sebagai Variabel Intervening (Studi Kasus pada BPK RI Perwakilan Provinsi Jawa Tengah). Universitas Negeri Semarang. Skripsi

Gautama S, Ibnu dan Muhammad Arfan, (2010), Pengaruh Kepuasan Kerja Profesionalisme, dan Penerapan Teknologi Informasi Terhadap Kinerja Auditor (Studi Empiris Pada Kantor BPK RI Perwakilan Provinsi Aceh. Jurnal Telaah \& Riset Akuntansi.

Ghozali, Imam, (2013), Aplikasi Analisis Multivariate dengan Program IBMSPSS 21 Update PLS RegresiI, Edisi 7, Penerbit Badan Penerbit Universitas Diponegoro, Semarang. BUKU

Hartha, Cok Nirmala, (2015), Pengaruh Kompensasi Finansial, Kompleksitas Tugas, dan Locus Of Control Pada Kepuasan Kerja Auditor.Skripsi S-1 Fakultas Ekonomi dan Bisnis Universitas Udayana, Bali. 
Iskandar, T.M, dan Zuraidah, M.S. 2011. Assessing The Effects of Self-Efficacy and Task Complexity on Internal Control Audit Judgment. Asian Academy of Management. Universitas Sains Malaysia. AAMIAF. Vol.7, No. 1. Pp.

Luthans, Fred. 2006. Perilaku Organisasi. Edisi Sepuluh, PT. Andi: Yogyakarta

Mahardika, Samyana, (2015) Pengaruh Komitmen Organisasi, Komitmen Profesional, Motivasi Kerja, Kompleksitas Tugas dan Gaya Kepemimpinan Terhadap Kepuasan Kerja Auditor, Skripsi S-1 Fakultas Ekonomi Universitas Warmadewa, Bali.

Mohd-Sanusi, Z, dan Iskandar, T.M. 2007. Audit Judgment Performance: Assessing the Effect of Performance Incentives, Effort and Task Complexity. Managerial Auditing Journal, 22: 34-52

Mulyadi. 2014. Auditing: Edisi 6.Penerbit Salemba Empat. Jakarta.

Robbins, Stephen P., Judge, Timothy A. 2008. Perilaku Organisasi. Penerbit Salemba Empat. Jakarta.

Rotter, J.B. 1966. Generalized Expectancies for Internal versus Eksternal Control of Reinforcement. Psychological Monographs, Vol. 80, pp. 1-28

Sari, Diah Ratna dan Harlina Nurtjahjanti. 2015. Hubungan Antara Internal Locus of Control dengan Organization Citizenship Behavior (OCB) pada Karyawan. Jurnal Empati. Vol. 4. No. 2. Pp. 3742

Sososutikno, Christina. 2003. Hubungan Tekanan Anggaran Waktu dengan Perilaku Disfungsional serta Pengaruhnya Terhadap Kualitas Audit. Simposium Nasional Akuntansi VI. Surabaya

Umam, Khaerul. 2010. Perilaku Organisasi. CV. Pustaka Setia: Bandung

Wibowo. 2015.Manajemen Kinerja: Edisi 5. Penerbit: Rajawali Pers. Jakarta. 